\title{
Legal Protection For The Winner Of Execution Auction Over The Auction Object That Sued Before District Court
}

\author{
Dwi Ayu Rachmawati \\ Program Studi Magister Kenotariatan \\ Pasca Sarjana Fakultas Hukum Universitas Brawijaya \\ Jl. MT. Haryono No. 169, Malang 65145, Indonesia \\ Email : dwiayurachmawati@gmail.com \\ Nurini Aprilianda \\ Program Studi Magister Kenotariatan \\ Pasca Sarjana Fakultas Hukum Universitas Brawijaya \\ Jl. MT. Haryono No. 169, Malang 65145, Indonesia \\ Email : - \\ Siti Noer Endah \\ Program Studi Magister Kenotariatan \\ Pasca Sarjana Fakultas Hukum Universitas Brawijaya \\ Jl. MT. Haryono No. 169, Malang 65145, Indonesia
}

Email :-

\begin{abstract}
In the process of auction execution often arise a lawsuit over the auction implementation, this is because the auction of execution is done not on the willingness of the owner of the goods themselves but because the law gives authority to the creditors to conduct public auction on the guarantee of debtors that default. So in the process of conveyance of auction object from the seller to the auction buyer often cause problem, such auction object can not mastered by auction winner. The purpose of this research is to know legal protection for the auction winner of mortgage rights auction execution in mastering the auction object that sued before district court. This research done by normative method. Based on result of the research can be concluded the winner of the auction can not mastering the auction object immediately due to civil suit over the auction object. This as arranged in article 3 paragraph (1), (2), and (3) of the regulation of the Minister of Agrarian Affairs and Spatial/head of the national land Agency Number 13 Year 2017 Regarding The Blocking and Confiscation which stipulated that if there found dispute or conflict over land rights law that became object of the auction then blocking would undertake. Other rules that give legal protection for the auction winner provided by regulation of the Minister of finance Number 27/PMK. 06/2016 Regarding Guidance for Auction Implementation, HIR. In addition, in article 19 paragraph (1) of Act Number 8 Year 1999 Regarding The Protection of Consumers and in the jurisprudence of the Supreme Court of Republic Indonesia verdict Number 1068 K/Pdt/2008 Dated January $21^{\text {st }}$, 2009 in Supreme Court National Conference Year 2011.
\end{abstract}

Key Words : Legal protection, Auction winner, Execution of mortgage. 


\section{INTRODUCTION}

Bank is one of the intermediation institution that its primary activity is to give credit distributed to society by credit agreement. ${ }^{1}$ This agreement consist of primary agreement and assesoir agreement. Primary agreement is the credit agreement while assesoir agreement is a warrant agreement by the debitor.

For the land right can be credit warrant it must use mortgage. Function of credit warrant agreement is to protect creditor and to guarantee the payment or fulfillment of obligation by the debitor to the creditor and to give ease for the creditor in dispute settlement in case of default (wanprestasi). ${ }^{2}$ This protection is important in case of bad debts that is when debitor can not fulfill their credit obligation including the primary, the interest and others in proper time.

If the debitor does not fulfill the payment obligation after process of letter of summons, then the certificate of land mortgage have an executorial power, whether it have designated before nor it have not designated in the mortgage deed, because purpose of mortgage is to guarantee debt of the debitor. If the debitor default, right on the land that burdened with mortgage right can be sold through the general auction without the agreement of mortgage principal. The mortgage principal can not object the sale.

To implement auction of credit guarantee in form of mortgage, it use the execution auction procedure. Execution auction have a high lawsuit potention. This is because in the execution auction, most of the goods auctioned without agreement of the owner and oftentimes there are a lot of parties who feel their interest interrupted with the auction. Usually these parties will filled a lawsuit to the court, fight for their right related with the auction object. This caused there are a lot of civil cases and administrative law cases regarding auction.

Civil lawsuit causing blocking of the auction object by National Land Agency so the title transfer process by the auction winner can not fulfilled. This detriment the auction winner because he can not mastering the object auction he have won.

Based on background above, legal issues in this article are : does the auction winner can mastering auction object that he won in the auction of mortgage execution? How is the form of legal protection to the winner auction of the mortgage execution that filled before district court?.

Mariam Darus Badrulzman.(1994). Aneka Hukum Bisnis, Bandung: Alumni, p.105-106.

Mochammad Dja'is.(2004). Pikiran Dasar Hukum Eksekusi, Semarang: Fakultas Hukum Universitas Diponegoro, p. 6 


\section{METHOD}

Method of research is normative research, that is by analyses articles, principles and doctrine connecting with issues that will research. Approach in this research are statute approach, analytical approach. Statute approach used to analysed the mastery of auction object by the winner of mortgage execution auction as regulated in Indonesian positive law. While analytical approach used to study how the legal protection for the auction winner of the mortgage execution that filled before the district court.

\section{ANALYSIS AND DISCUSSION}

The Mastering of Auction Object By The Auction Winner That Sued Before District Court

\section{Mortgage Right As The Warrant of Credit Banking}

Mortgage Right as the warrant of credit banking is a warrant right that encumbrance over land right in form of mortgage right that aimed to repayment the specified debt that give main position to the specified creditor against other creditor. In other words first mortgage right holder more preferent over other creditor.

Mortgage right contain right to execute the compliance of debt to the warrant object, when the debt have due date and it have billed but the debitor can not afford to repay then the debitor been declared have default (wanprestasi). The creditor have an authority to execute the warrant object directly without intercessison from judge because the warrant agreement contain executorial title that have binding and definitive power as of court judgement. Direct execution to the warrant object may by sold it in public and its outcame calculated to repayment the debt. Moreover since the existence of commitment to sold by own power, then the creditor may sold the warrant object in public based on parate eksekusi.

Execution process over a mortgage right by creditor basically is not difficult. This is because in the mortgage right certificate written words "For The Sake of Justice based on One True God" that have executorial power just as court decision that have permanent legal force, the first holder mortgage right have right to execute the warrant object directly in case of the debitor broke the commitment. This is based on the power that had given by the debitor and the legislation to the creditor.

Article 6 of Mortgage Right Act gives an authority to the mortgage right holder to sell the mortgage right object on its own power through public aution and take the debt repayment from selling outcame if the debitor default. First holder of mortgage right do not need ask an agreement from the mortgage right principle and do not need establishment from the head of 
district court to implement the execution. ${ }^{3}$

Theory used as the analysis tool in this article is Theory of Legal Certainty by Gustav Radbruch, that is when a rule made and promulgulated certainly because it regulate clearly and logically. Clear mean do not raise doubt (multy interpretation) and logic mean do not raise impact, fuzzy of norm, conflict of norm in a norm system. Furthermore, legal certainty theory according to Satjipto Rahardjo that said legal force contain in text, that is text and phrase used, raising meaning of the rules in order to make legal certainty.

In this thesys analysis, legal certainty had given by Act Number 4 year 1996 Regarding Mortgage Right On Land and The Objects Conecting With Land, article 6 stipulated that the authority given to the first Mortgage Right Holder to sell object of mortgage right by its own power through public auction and take debt repayment from the outcame, if the debitor default. Based on that rule, PT BRI cabang Kediri as the first Mortgage Rigt holder have right to sell the warrant object through public auction without asking agreement from the debitor as the mortgage right principal.

\section{Mastery of Auction Object by The Auction Winner}

Based on Article 1 numbers (22) Minister of Finance Regulation Number 27/PMK.06/2016 Regarding Guidance of Auction implementation, auction winner is the winner whether person or corporation/business entity that propose the highest offer and approved as the auction winner by the auction officer. Winner in the auction of the mortgage right execution legalized by the auction officer and written in Auction memory. Auction of the mortgage right as a legal action raised right and obligation to the auction winner.

According to Purnama Tioria Sianturi, right and obligation of the auction winner are : ${ }^{4}$

a. Right of Auction Winner.

1. Related to Object Transition, Vendu Reglement also regulate right of the auction winner. In article 42 Vendu Reglement, the auction winner have right to get coppy or quotation of the official report that have legalized that named quote of auction memory. The quote of auction memory will used as deed of sale and purchase for the purpose of title transfer of auction object. (article 94 paragraph (2) part (a) Regulation of Financial Ministry Number 27/PMK.06/2016 Regarding Guidance of Auction Implementation);

Remy Sjahdeini.(1999). Hak Tanggungan, Bandung: Alumni, 1999. p.164-165.

4 Purnama Sianturi.(2013).Perlindungan Hukum Terhadap Pembeli Barang Jaminan Tidak Bergerak Melalui Lelang, Edisi Revisi, Bandung: CV. Mandar Maju. 
2. Related to the Hand Over of Goods Ownerships Document, auction winner have right to get the authentic of Goods ownerships document.

3. Related to the Object Ownership, after the auction winner carry out his obligation to pay the auction and tax/other legal loan in a given time period, auction winner have right to own the auction object physiccaly.

b. Auction Winner Obligation.

In article 75 Financial Ministry Regulation Number 27/PMK/06/2016. Seller prevented from taking or owning the object that he bought before satisfy the obligation of aution payment and tax and other legal loan according to the legislation.

Auction implementation do not apart from right and obligation of the parties. Auction party is a person or a legal corporation, unless prevented by the rule.

Process on the ownership of object auction is not easy. As the case example in this article, that Mr Jauhari Bastomi have declared as the auction winner. This written in quote of auction memory Number 1032/2014 dated September $26^{\text {th }} 2014$ on the implementation of an auction in the Office of Service on State Wealth and Auction in City of Malang. Mr Jauhari Bastomi can not get his right to mastering and making title transfer on the auction object he have won. This is due to the civil lawsuit filled by the first owner of aution object, that is $\mathrm{Mr}$ Ichwanudin.

Article 3 paragraph (1), (2) and (3) Regulation of Ministry of Land and Spatial Affairs/Head of State Land Agency Number 13 Year 2017 Regarding Procedure on Blocking and Consfication mention:

1. Record blocking taken to the land right upon legal action or legal affair, or due to dispute or land conflict.

2. Record blocking as refer in verse (1) submitted:

a. In order for legal protection for the interest of land that asked to be blocked;

b. At most once a time by one applicant upon one land object

3. Right upon land that in its land book have a blocking note can not conducting land register data maintenance.

In the article explained that if there is a dispute or conflict on land right that been auction object then blocking will conducting. This is for the protection of the applicant. Maintenance of land registration can not conduct based on this blocking. This rule underlied State Land Agency to blocking right of land that been auction object. Thereby auction winner can not conduct title transfer and mastering auction object he won immediately although he 
have pay off all his obligation as the auction winner.

Blocking filled by interested parties that land right or propriety right of flats will be object in the court to written in land book. Time period of blocking maximally 30 days, otherwise if followed with collateral consfication award that certified coppy of execution official record submitted to the Head of Land Office. ${ }^{5}$

Blocking registry can be abolished due to some things as stipulated in article 15 regulation of agrarian and spatial ministry/head of state land agency number 13 year 2017 regarding Procedures on Blocking and Consfication, i.e:

1. Period time of blocking ended and not lengthens;

2. Party who ask for registry have revoke the demand before period time ended;

3. Head of the office remove the blocking before period time ended; or

4. Court order in form of establishment or decisions.

Related to that, arrangements regarding the issuance of certificate have suffered obstacle, if in that land right found lawsuit over that land. The auction winner of the land object that sued before court can not filled application for issuance of certificate. This is as stipulated in article 31 paragraph (2) Government Regulation Number 24 Year 1997, i.e:

"if in the land book contain record as reffered in article 30 paragraph (1) (b) with regard to yuridical data, or record as reffered in article 30 paragraph (1) (c),(d), and (e) with regard to physical data nor yuridical status of certificate issue suspended until the concerned record abolished."

In that rule it is clear that issued of land certificate suspend in case of there found lawsuit over the concerned land until the concerned record abolished.

The legal certainty theory used as analyzing tool in this article is legal certainty theory by Gustav Randbruch. This theory said that a rule made and promulgated certainly because it regulate clearly and logically. Clear mean that it does not raise hesitations (ambiguous/multi interpretation). Logic mean that it does not raise collision, vague of norm, nor conflict of norm. Other theory is legal certainty theory by Satjipto Rahardjo, explained that the legal force contain in text, that are words and phrase as used, thereby raising meaning that create legal certainty.

The mastering of auction object by the auction winner according to article 72 PMK Nomor 27/PMK.06/2016 regarding implementation of auction mention that the auction

5 https://acch.kpk.go.id/images/ragam/makalah/pdf/labuksi/09-PERAN-KEMENTERIAN-ATRBPN-SekjenKementerian-ATRBPN.pdf, accessed at April $3^{\text {rd }}$ 2018, at 10:37 WIB. 
winner may mastering or own the auction object after fulfill obligation for payment of auction and tax or other legal collection according to acts. In fact, in Mr Jauhari Bustomi case who can not processed the mastering and transition of right on the auction object he won even he had fulfill his obligation. This is base on article 3 paragraph (1) Regulation of Ministry of Land and Spatial Affairs/Head of State Land Agency Number 13 Year 2017 Regarding Procedure on Blocking and Consfication mention: Record blocking taken to the land right upon legal action or legal affair, or due to dispute or land conflict.

If the certificate is blocked, submission for new certificate issue will not happened. This is as regulated in article 31 paragraph (2) (b) Government Regulation Number 24 year 1997, that is "“if in the land book contain record as reffered in article 30 paragraph (1) (b) with regard to yuridical data, or record as reffered in article 30 verse (1) (c),(d),and (e) with regard to physical data nor yuridical status of certificate issue suspended until the concerned record abolished.

Rules concerning mastering of auction object have different regulation. One rule guarantee the mastering of auction object as long as the auction winner fulfill the obligation, while other rule prevent the auction winner to mastering the land he have won in the auction immediately due to blocking as a result of dispute or conlict over that land.

\section{Form of Legal Protection for The Winner of Mortgage Right Execution Auction That Sue Before The District Court}

Auction implementation particularly execution auction, subsist high potention of lawsuit. This is due to one's dissasatisfaction on that auction. The lawsuit may submit before or after the aution implementation. Lawsuit before auction implementation intended to postpone auction implementation. While lawsuit after auction implementation intended for many different reason.

As a rechstaat, every citizen whose right have violated, have right to submit lawsuit or pleading before court as atool to defend his right. For lawsuit against auction implementation most of all due to act against the law. As a rechstaat, every citizen whose right have violated, have right to submit lawsuit or pleading before court as atool to defend his right. For lawsuit against auction implementation most of all due to act against the law.

As a protection for interested parties in auction process, article 4 Regulation of Finance Minister Number 27/PMK.06/2016 Regarding Guidance for Auction Implementation regulate that "auction that have implemented appropriate with effective rule, may not abrogated. This rule give represif protection that is if lawsuit submit against auction process 
then auction process may not abrogated arbitrary if auction process appropriate with rule in legislation Regarding Auction. ${ }^{6}$

Furthermore protection for auction winner given in article 17 paragraph (1), (2) and (3) Regulation of Financial Minister Number 27/PML.06/2016 Regarding Guidance on the Implementation of Auction.

Article 17

(1) Seller have responsibility to :

a. Legality of object ownership;

b.Legality of auction requirement document;

c. Handover of moving objects and/or immovable objects.

d.Handover of ownership document to buyer; and

e. Determination of limit value.

(2) Seller responsible toward civil lawsuit and/or criminal charge that arise as a qonsequences from legislative in auction plane can not fulfill by the seller

(3) Seller responsible over compensation demand toward emerges of loss, in case of not meet responsibility as refer in paragraph (1).

Rule in article 17 paragraph (1),(2) and (3) Regulation of Financial Minister Number 27/PMK.06/2016 Regarding Guidance of Auction have regulate clearly about seller responsibility. In execution auction the seller are creditor or bank, because in execution auction seller have empowered sale through auction to creditor. Based on act regarding Mortgage Right, creditor or bank as the holder of mortgage right have power to transact public sale through auction over mortgage right object from debitor who have defaults.

Article 1 (c) explained that seller responsible to "handover of movable object and/or immovable object". This rule is a base for auction winner legal protection over possessing of object auction he have won. In this case bank as a seller shall responsible to handover auction object. Furtheremore in paragraph (2) mention that when there are civil lawsuit or criminal charge over insatiable of legislation regarding auction then seller shall be the one who responsible.

If seller can not fulfill his obligation as stipulated in paragraph (1) and loss arrised then seller shall responsible. This is one form of legal protection arranged in Regulation of Finance Ministry. Base on that rule, in case of auction object can not owned, auction winner may ask responsibility from seller since one of seller obligation is handover the object.

Even fault in auction transaction emphasized to seller, but in fact auction office shall have responsibility too. However auction office considred have no responsibility due to

6 Wirjono Prodjodikoro.(2000). Perbuatan Melanggar Hukum, Bandung: CV Mandar Maju, p.6-7. 
arrangement in auction memory do not embody legal protection for auction winner at all.

Prudent principle shall undertaken by auction officer, because clarity of auction object is one of auction officer duty. Article 41 Government Regulation Number 24 Year 1997 Regarding Land Registration said that Head of Auction Office no later than 7 days work before a land auctioned, must ask information regarding land status and other information about the land to local land office. Head of Auction Office must declined auction transaction if things concerning the registered land unclear.

Legal protection for buyer not merely a need of a few people, but the need for society. Consumen or auction buyer that must protected are the one who have good faith. Good faith buyer is the one who have fulfill all of his obligation but do not receive his right. Good faith is an important part in contract . however there are no definite definition of good faith. A lot of good faith definition make good faith definition get unclear. To get clear definition of good faith must refer to interpretation from court practice.

There is no written rule regarding good faith buyer. However it can conclude implicitly through Article 1338 verse (3) The Civil Code that said agreement/contract shall implement with good faith. Criteria of good faith is not arranged in any Indonesia legislation. But this reflected in Supreme Court of Repuclic Indonesia verdict date August $28^{\text {th }} 1967$ Reg. No. 821 K/Sip/1974, mention that auction buyer who buy object through process of public auction by State Auction Office is a good faith buyer and must protected by The Act. Judge consideration with respect to good faith whereabouts do not depent on legality of auction process. That can be seen from judge decision that devide the decision into decision of legality and decision of illegality, however that do not affect the statement regarding good faith buyer.

Concept from Purnama Sianturi give a legal certainty and fairness for the auction buyer, bank as debitor and creditor and other interested parties. Auction as legal institution must guarantee legal certainty, fairness and benefit. Auction in a mortgage execution auction is executorial verkoop complying with article 200 verse (1) HIR and article 216 verse (1) RBG. Article 216 verse (1) RBG said that :

Selling of object that confiscated undertake with help of Auction Office, or according to situation that will considered by the Head, or people who will undertake the consfication or other people who can be trusted, that assigned by the head for that and live in the place where the selling undertake or near that place.

After confiscation, the Act determined selling of confiscation object by intercession of Auction Office. Auction is not an agreement/contract, because auction is an authority in 
procedural law plane, and part of execution that is in materill plane. Auction is also an execution of a main agreement. Buyer's right have fully protected by the Act, because the buyer considered have good faith.

Other decision from Supreme Court of Republic Indonesia that give certainty for legal protection for auction winner is Supreme Court Decision of Republic Indonesia Number 1068 K/Pdt/2008 date January $21^{\text {st }} 2009$ in Supreme Court Conference year 2011:

1. Auction that undertook based on decision that have legal force can not abrogated

2. Buyer over object that become dispute based on official report and Auction memory that base on decision that have legal force is a good faith buyer therefore must protected.

3. If in the future were found decision that contrary with decision that have legal force and stated that decision which have legal force no longer binding, that decision can not use as a reason to abrogate auction (moreover asking for confiscation or blocking). What can be done is demand for compensation over dispute object from the auction applicant.

Same principle apply to third party who claim ownership over the warrant, may demand for loss in form of certain nominal to the debitor/warrant principle. Third party may not demand for abrogation of credit accad or warrant that binded as mortgage, moreover demand for confiscation or blocking over the land. Creditor and auction winner are third party who have no knowledge over private dipute of the debitor/warrant principle.

Base on legal protection theory by Philiphus M. Hadjon, there are two kind of legal protection, that are Preventif Legal protection and Represif Legal Protection. Preventif legal protection give the subject chance to put objection or give an argument before government decision getting definitive. That is to prevent dispute occurrence. In this case, there is no preventive legal protection for auction winner. There are no legislation that give protection for buyer before auction transact to prevent breaking of law that can harm auction buyer.

Represif legal protection aimed for dispute settlement, including its settlement before court. In this case represif legal protection have given to the auction buyer by legislation, that are:

1. Article 4 Regulation of Finance Ministry Number 27/PMK.06/2016 Regarding Guidance of Auction Implementation.

2. Article 17 verse (1), (2) and (3) Regulation of Finance Ministry Number 27/PMK.06/2016 Regarding Guidance of Auction Implementation. 
3. Article 19 verse (1) Act Number 8 Year 1999 Regarding Consumen Protection

4. Jurisprudence of Supreme Court of Republic Indonesia No. $1068 \mathrm{~K} / \mathrm{Pdt} / 2008$ date $21^{\text {st }}$ January 2009 in Supreme Court National Meeting year 2011.

To make the rules can protect auction winner then those must filled in lawsuit before court. That is real form of legal protection. The lawsuit includes demands of right that conceived dispute and at once as a basis for case investigation and vindication over righteousness of right.

\section{CONCLUSSION}

The auction winner can not holding the auction object that he won immediately due to civil lawsuit on that auction object. This stipulated in article 3 verse (1),(2) and (3) Regulation of Minister of Agrarian and Spatial affairs/Head of State Land Agency Number 13 Year 2017 Regarding Procedure on Blocking and Confiscation that explained if there were dispute or conflict over the land that be auction object then blocking will undertake. Vendu Reglement and Vendu Instructie that become main legal basis for auction in Indonesia do not give preventive legal protection to auction winner. So as clasul in auction memory that do not give legal protection for auction winner.

Legal protection given in Regulation of Finance Ministry number 27/PMK.06/2016 regarding Guidance of Auction Implementation, and HIR in case of auction object discharge may ask help from District Court. In addition in Supreme Court Of Republic Indonesia decision number RI No. 1068 K/Pdt/2008 and Juriprudence of Supreme Court of Republic Indonesia Number No. 1068 K/Pdt/2008 year $21^{\text {st }}$ January 2009 in Supreme Court National Meeting Year 2011.

\section{BIBLIOGRAPHY}

\section{Books}

Mariam Darus Badrulzman.(1994). Aneka Hukum Bisnis, Bandung, Alumni.

Mochammad Dja'is.(2004). Pikiran Dasar Hukum Eksekusi, Semarang: Fakultas Hukum Universitas Diponegoro.

Purnama Sianturi.(2013). Perlindungan Hukum Terhadap Pembeli Barang Jaminan Tidak Bergerak Melalui Lelang, Edisi Revisi, Bandung: CV. Mandar Maju.

Remy Sjahdeini.(1999). Hak Tanggungan, Bandung, Alumni.

Wirjono Prodjodikoro.(2000). Perbuatan Melanggar Hukum, Bandung: CV Mandar Maju. 


\section{Legislation}

Act Number 8 Year 1999 Regarding Consumen Protection

Regulation of Finance Ministry Number 27/PMK.06/2016 Regarding Guidance of Auction Implementation.

Regulation of Ministry of Agrarian and Spatial Affairs/Head of State Land Agency Number 13 Year 2017 Regarding Procedures of Blocking and Confiscation.

Jurisprudence of Supreme Court of Republic Indonesia No. $1068 \mathrm{~K} / \mathrm{Pdt} / 2008$ date $21^{\text {st }}$ January 2009 in Supreme Court National Meeting year 2011.

\section{Worldweb}

https://acch.kpk.go.id/images/ragam/makalah/pdf/labuksi/09-PERAN-KEMENTERIAN-

ATRBPN-Sekjen-Kementerian-ATRBPN.pdf, accessed April $3^{\text {rd }} 2018$, at 10:37 WIB. 